\title{
3 Komshuluk (Good Relations Between Neighbours) and Ressentiment Against Members of a Different Religion
}

\author{
Narrated 'A'ishah: \\ I said, "O Allah's Apostle! I have two neighbours and would like to know to which of them I \\ should give presents." He replied, "To the one whose door is nearer to you."
}

(al-Bukhari Hadith ${ }^{157}$ 3:460)

\subsection{Komshuluk as a Cultural Strategy of Peaceful Coxistence}

This chapter examines the relations between Bulgarian-speaking Muslims and their Orthodox Christian neighbours within the framework of two prevalent narratives concerning non-coreligionist neighbours. One narrative focuses on omshuluk $^{158}$, good relations between neighbours and in doing so reflects a cultural strategy developed by the local community; the other reflects a latent sense of mutual ressentiment harboured by Muslims and Orthodox Christians. Though only mentioned in conversations with coreligionists ${ }^{159}$ and not reflected in current cultural practice (there are no active conflicts between the local Muslim and Christian populations), the ressentiment narrative offers a revealing insight into the motivations of my respondents, lurking in some cases under the outwardly correct relations with which they may be closely interconnected, as noted by Tsvetana Georgieva (Georgieva 2003, p. 28) ${ }^{160}$. This type of narrative gives voice to the mutual fears harboured by both groups, which are rooted in the collective memory (or postmemories) ${ }^{161}$ of past violence including 19th- and 20th-century atrocities.

157 A story or account of an event from the life of the Prophet Muhammad, including Muhammad's sayings on a given subject, boosted by the authority of the reporting party; hadiths form the basis for the Sunnah and are the second source of Muslim law, after the Qur'an. Translation: Hadith of Bukhari, http://www.sacred-texts.com/isl/bukhari/bh3/bh3_457.htm

158 An affirmative term for neighbourly relations derived from Turkish (komşuluk). Perhaps significantly, Bulgarian has a neutral, Slavic term for "neighbour" (sŭsed), but this is used less frequently. According to the Bulgarian sociologist Ivan Hadziyski, the word komshuluk also used to refer to wicket gates separating neighbouring homesteads, which were always kept unlocked (Georgieva 2003, p. 9) unlike the tall, locked gates facing the streets, a familiar element of Ottoman architecture.

159 When asked directly whether they tend to keep such topics out of their conversations with noncoreligionist neighbours, the respondents said they "no longer did".

160 Ts. Georgieva does not use the term "narrative" but she talks about the two sides of the code of coexistence (Georgieva 1995, p. 153). Cf. Section 3.2.

161 See (Hirsch 2012). In an interview for Columbia University Press, Hirsch explains that postmemory "describes the relationship that the 'generation after' bears to the personal, collective, and 
This ressentiment ${ }^{162}$ or fear is not based on direct personal experience; it has been orally tranmitted within the community by elders or deceased relatives, and stems from each group's past experience. For Christians, this experience dates back to the period of Ottoman decline and struggle for Bulgarian liberation; for Bulgarian-speaking Muslims, such narratives focus on the period of the Balkan wars. Unlike the Christian stories, which are essentially carbon copies of images from Bulgarian martyrology codified in historical writings, the stories told by Bulgarian-speaking Muslims cannot rely on what Robert Redfield calls a "great tradition". Each side's narrative serves to impose a certain category on "the close Other" (a non-coreligionist neighbour), and reflects mutual attitudes of Muslims and Orthodox Christians. The two versions are structurally equivalent and comprise analogous components.

To interpret those narratives I analyze their context (specific interview situations, the identity of my narrators, whether the information is shared openly and freely, or perhaps hesitantly or inadvertently?) and their symbolic meaning. This kind of closely guarded and suppressed cultural content is of particular interest since it offers an insight into the hidden roots of cultural practice. It differs from the official version, and is shared on very rare occasions in long, repeated conversations. I never pressed my respondents for the withheld information nor did I impose my own interpretations directly, i.e. by not asking whether or not Muslims and Christians had ever committed atrocities against each other in the area.

Obtaining this cultural content required a cautious approach in which information shared in the early stages of interviews was treated with a grain of salt according to the principle that "practical logic ... is unaware of the principles that govern it" (Bourdieu 1990, p. 92). Accordingly, to engage in a practice, social actors (Bourdieu's agents)

cultural trauma of those who came before - to experiences they 'remember' only by means stories, images and behaviours among which they grew up" (http://www.cup.columbia.edu/static/interviewmarianne-hirsch accessed 23.09.2014).

162 The „revival process” in Bulgaria probably played an important role in generating the ressentiment. This might explain why such ressentiment is more palpable in Muslim-Christian relations in Bulgaria compared to the neighbouring Macedonia (cf. Lubaś 2011, p. 248). Based on his field research in Dolna Reka, Marcin Lubaś concludes that cohabitation is possible between communities of different religions in a form that is free from all ressentiment and "based on mutual acceptance as expressed through customs, mutual help in daily life and a positive opinion about the neighbours" (Lubaś 2011, p. 249, translated from Polish). To emphasize: my discussion of the influence of ressentiment on the dynamics of interreligious and neighbourly relations does not imply that all relations between neighbours of different faiths must necessarily have an underpinning of mutual ressentiment. Neighbourly relations may take on a range of different forms. Many of the Muslims and Christians are not just neighbours, they are also personal friends. However, I believe that friendships between non-coreligionist neighbours may be quite distinct from, and not mutually exclusive with, fears harboured in some historical circumstances towards neighbours of a different faith, reflecting differences in political interests. Accordingly, I devote an entire chapter to this problem. 
must forget its social meaning. The social actors remain aware of the underlying reasons for the practice they engage in, however they keep such reasons hidden from themselves and from others. „It is the curse of objectivism that, here as in all cases, where it confronts collective belief, it can only establish, with great difficulty, truths that are not so much unknown as repressed" (Bourdieu 1990, p. 107).

My task involved deconstructing the social meaning of the practice of good neighbourly relations. Formulated in this manner, "objectivist critique is justified in questioning the official definition of practices and uncovering the real determinants hidden under the proclaimed motivations" (Bourdieu 1990, p. 108). According to Bourdieu, the perspective of a social actor (including the perspective of my respondents) will always differ from the objectivizing prospective of external observers who seek to impose a theoretical model on a given social practice ${ }^{163}$.

Even where researchers succeed in actually discovering the motivations of social actors, their theoretical conclusions usually provoke resistance or caution from the actors in question because they may disrupt a social practice by bringing certain hidden meanings to the surface. Scholarly conclusions usually undermine the official interpretations which a group shared in order to conceal its true motivation. Knowing such officially sanctioned motivations, even where they are not actually true, is an important element of the cultural strategy practised by a group - in this case, the coexistence of neighbours professing different faiths, a practice stemming from cultural affinity and tacitly accepted by the social actors ${ }^{164}$. This affinity means that Muslims and Christians in the area know exactly which behaviours or topics of conversation will be acceptable in mutual interactions, and which should be kept out of the conversation:

Z.: The Muslims and us, we live as neighbours. Perhaps there might be some things that get bottled up inside, but they're never discussed. We don't mention it, and neither do they. But life goes on, so far we have coexisted well... There are no tensions between us. (M, Ch, Interview 53, 2005)

By reconstructing the strategy of peaceful coexistence, practiced by both religious groups as a key element of the cultural affinity which brings them together, the

163 In Bourdieu's understanding of the problem, the practical sense (i.e. that which belongs to social praxis) never overlaps with objective truth or objectivising scientific theory on the subject (Bourdieu 1990). 164 According to M. Herzfeld, this category is "a reasonably effective heuristic device for locating the specific dynamics of cultural embarrassment and solidarity" (Herzfeld 2005 p. 34), defined as "a recognition of the deep sense of a shared fatality, something to be treasured precisely because it is at once in permanent and private, that seems common to virtually all intimacy" (Herzfeld 2005, p. 43). At the same time, "the content of cultural intimacy is ... highly labile. It shifts with the ideological winds of history, sometimes in wildly unpredictable ways” (Herzfeld 2005, p. 57). Therefore, “one decade’s embarrassment may also become another's pride and joy” (Herzfeld 2005, p. 64). According to M. Herzfeld, "while particular social interactions are always, and necessarily, acts of self-reification, their content and form and both nevertheless perpetually in flux" (Herzfeld 2005, p. 77). 
researcher runs the risk of rendering it less effective by revealing cultural content carefully kept under wraps by the local community in order to preserve the status quo. Where such strategies of silence ${ }^{165}$ serve the good cause of peaceful coexistence, this becomes an ethical problem. Depending on who reads such research, such research can be turned to good or bad use, affecting the community. Ethnographic data will be put to a different use by an academic or by a politician looking for votes ${ }^{166}$.

Incidentally, the strategy of silence ${ }^{167}$ goes beyond relations with neighbours of different faiths, and aplies to relations with neighbours sharing the same faith as well:

M.L.: Are there any obligations towards the neighbours in these parts? What does one have to do to stay on good terms with one's neighbour?

M.: Well, you need to have peace in your heart. You mustn't hurt your neighbour, provoke him. Say, he comes to your house drunk and says something bad, then keep your mouth shut! Obviously, he'd never say anything like that when sober. So it's better not to say anything. You need to be patient, stay calm, consider your options. That's how I see it. Listen, I have those neighbours next door, there's nothing but a fence separating us. I can't complain or provoke them to say bad things, to be rude to me. And myself, I never open my mouth to say anything against them. That doesn't happen. We are good to each other. When I need something it's like, "Neighbour, could you please help me?" I can borrow things from her when I need them - rice or milk, or anything. If they have a cow, the woman will share [the milk - M.L.] with me. The point is, this has to be a mutual thing. They will share things with us even if they have to go hungry. I do the same. That's how we live in harmony with our neighbours." (W, Ch, Interview 35, Garmen 2006)

In this passage, the woman encapsulates the strategy of good relations in daily life, an approach where mutual assistance and restraint are used to avoid antagonizing

165 As the Polish anthropologist Z. Sokolewicz notes, "silence plays an important social function, indirectly contributing to group cohesion (...). For instance, we may deem as positive those suppressed topics which may be involved in the process of socio-lies they should and gradual introduction of information to children, such as the information about sexual life (treated as a dangerous area subject to numerous taboos and requiring initiation) and many other social aspects of life" (Sokolewicz 2008, p. 79-80, translated from Polish). G. Szwat-Gyłybowa, a Polish Slavist, writes about this problem in more detail: "silence is a Janus-like phenomenon and cannot always be reduced to a psychological mechanism conditioned by individual or collective experience of repressing inconvenient content. As we know, suppression of topics in the social sphere is also associated with the strategies of dissembling and mimicry, theatricality of everyday behaviours, the necessary grain of hypocrisy in the workings of society which helps to generate such disparate phenomena as the cultural game of appearances (which at its best is designed to avoid hurt on the part of the addressee) and manipulation (calculated at gaining some kind of power over the addressee)" (Szwat-Gyłybowa 2008, p. 10, translated from Polish).

166 Not coincidentally, Bulgarian-speaking Muslims become a topic of debate before elections (cf. section 3.5).

167 I borrow this term from Z. Sokolewicz (Sokolewicz 2008, p. 81). 
the neighbours. In the following section I offer a more comprehensive analysis of this phenomenon, focusing in turn on Muslim and Christian neighbours.

\subsection{The Narrative of Komshuluk}

When asked, "What is it like to live side by side", neither religious group reacted to the question as to something neutral or innocent. My respondents seemed familiar with the question, and their responses tended to fall back on the concept of komshuluk ${ }^{168}$. The importance of the concept of komshuluk for the coexistence of Muslims and Christians in culturally mixed areas of Bulgaria was first made popular by a research project headed by Tsvetana Georgieva and her team from the Center of Ethnology, Faculty of History, University of Sofia, carried out in 1993-1994 in the area of Asenovgrad, Razgrad, Zlatograd and Ruse. Georgieva noted that in ethnically mixed regions komshuluk was "a complicated and traditionally managed system of rules relating to ongoing personal and social contact between people belonging to different religious and ethnic groups" (Georgieva 2003, p. 9, translated from Bulgarian). According to Georgieva, all members of such communities understand the system, which is geared towards maintaining a peaceful coexistence by keeping the groups separate and respecting their ethnic and religious differences. The phenomenon, which can be found throughout the Balkans, is not confined to the heterogeneous communities of Bulgaria. Xavier Bougarel offers a similar view, explaining that the practice of komshuluk regulates the relations between neighbouring groups while preserving their structural distinctiveness (cited in: Hayden 2002, p. 206).

In addition to peaceful coexistence, the historian Klaus Roth lists three other models of coexistence which are not fixed but rather can fluidly replace one another (Roth 2006, p. 20) ${ }^{169}$. This fluidity of ethnic relations, marked by transitions from peaceful coexistence to conflict, is also noted by Tsvetana Georgieva, who points out that Good relations between neighbours are just one side in the code of coexistence ${ }^{170}$,

168 The Slavic term sŭsed is also known in Bulgaria but all of my respondents used the word komshiya, which is used throughout the country.

169 The other two models (conflict-based and separation-based) are characterised by a lack of tolerance.

170 I believe strategy is an apter term than code since strategy implies an adaptable, contextdependent dynamics to social relations. In contrast, the term code implies a certain fixed matrix or structure to social relations, a kind of immutable given which is heritable, like genes. Accordingly, Ts. Georgieva's concept seems to be lacking the quality of uncertainty implicit in social relations. Social actors do not just simply perpetuate cultural conventions: they can also influence the course and form of such conventions or even discard them. I believe that good-neighbourly relations should rather be seen as a bottom-up cultural strategy developed by Muslims and Orthodox Christians over centuries of coexistence, which needs to be affirmed in everyday relationships of reciprocity. 
the other being a climate for conflict (Georgieva 1995, p. 155). Georgieva does not provide a more detailed description of the traumatic side of the code or offer any examples (Georgieva 2003, p. 7), but social research yields many illustrations of the point. In the case of the Central Rhodopes in Bulgaria, this would include the examples in Evgenia Ivanova's 2002 book on the process of state-orchestrated assimilation campaigns aimed at Bulgarian speaking Muslims between 1912 and 1989, Otchvŭrlenite 'priobshteni' ili protsesa, narechen vŭzroditelen (1912-1989), in which Ivanova cites Muslim and Orthodox Christian accounts from the 1990s. Such assimilation campaigns tended to destabilize the system of komshuluk, potentially preparing ground for a climate of ressentiment and adversarial acts against Muslims.

According to Ivanova's material, in some instances formerly close neighbours exerted pressure on their Muslims to change Turkish names to Bulgarian ones (Ivanova 2002, p. 99). The Norwegian anthropologist Tone Bringa discusses another, more traumatic instance of the principle of komshuluk being violated in a different Balkan region in Being Muslim the Bosnian Way... (1995) ${ }^{171}$. Bringa's description of a peaceful Catholic-Muslim community in a village near Sarajevo ${ }^{172}$ is highly reminiscent of the situation I found in the Rhodopes. Nonetheless, the community was marked by conflict and oppression during the war of 1993-1995. The Muslims were expelled, and their houses were destroyed: "After I revisited the village in May 1993 and had seen almost every Muslim house destroyed and all the Muslims gone, it was very difficult to sit down in peaceful Cambridge and continue writing this book. Nothing of what I had earlier said seemed real or to matter. As the same time, however, it became even more important to write about the community and the lived that had once, not very long ago, existed. It had been a community where people treated each other with dignity and respect, and understood how to accommodate each other's cultural differences" (Bringa 1995, p. xviii).

Such examples are a testament to the fragile nature of komshuluk and its vulnerability to external political factors (cf. Roth 2006; Hayden 2013), leading to a situation where war can trigger physical violence between neighbours formerly living on positively fraternal terms. An illustration of the sometimes barbaric forms this took on in Bosnia can be found, among others, in Love Thy Neighbour. A Story of War (1996), a book by the American reporter Peter Maass. In a refugee camp for Bosnians in Split, Maass met people who told him about the persecutions they experienced at the hands of their neighbours of a different nationality or religion, often lifelong friends in peacetime. One of his respondents, a refugee from Foca, told him how "thirty-five

171 In 1987-1988 Bringa studied the Catholic-Muslim relations in a single Bosnian village shortly before the war which dealt a fatal blow to the rules of komshuluk and led to a disintegration of neighbourly relations in 1993, when the village was attacked by Croatian troops.

172 Given the tense political situation in the region at the time of publication Bringa does not identify the village. 
men from his village were rounded up by Serbs from a neighbouring village and had their throats slit. ... They were killed by Serbs who had been their friends, people who had helped harvest their fields the previous autumn, people with whom they shared adolescent adventures and secrets, skinny-dipping in the Drina River on hot summer days, groping with the naughty girls of the village at night. All of a sudden, seemingly without reason, they had turned into killers" (Maass 1996, p. 6). Incidentally, this particular form of violence (throat-slitting) was often mentioned by my respondents where it formed an important motif in their narratives in recollection of dramatic events from the past that served as a foundation for the entire ressentiment narrative. My respondents tend to treat this particular form of murderous violence as a skeleton in the closet provoking fresh mutual fears every time it resurfaces in conversation.

The example of Bosnia raises the question: what kind of circumstances and internal dynamics must coincide to throw the centuries-old status quo so disastrously off-balance as to spur mutual enmity in people who have long enjoyed good relations? The conflicts in the former Yugoslavia in the 1990s and the islamophobic sentiment fuelled by the media in the wake of 9/11 must have had a negative impact on MuslimChristian relations worldwide, including the communities discussed in this book. This is why it is important to examine the feelings and symbols surfacing in the narratives of my respondents: What is it that they say about the Muslim-Christian relations, past and present, and about their mutual prejudices? As Franke Wilmer notes, stories "contain the emotions of past experiences, including trauma, and collective memories, conjured up by warmongering political wizards in the present" (Wilmer 2002, p. 30). Hence, "to understand how states are created and destroyed we must understand the construction and deconstruction of the narratives that underlie them" (Wilmer 2002, p. 30). The same applies to the processes of emergence and disintegration in communities. In order to understand how this process plays out in the mixed population of the Western Rhodopes with their two religions, we need to deconstruct the narratives describing good relations between the religions in the region.

Evidence of peaceful relations between Muslim and Orthodox Christian neigbors runs counter to Samuel Huntington's radical vision of the inevitable and imminent clash of civilizations. As noted by the anthropologist Michael Herzfeld, it also seems to run counter to experience-based ethnological knowledge about cultural contact ${ }^{173}$, which tends to be not so much hostile (pace Huntington) as ambivalent and highly

173 M. Herzfeld notes the misapplications of cultural ideas in political science, particularly singling out for his censure the ideas of Samuel Huntington as a kind of reprise of the 19th-century nationalism of the nation-state and an outlook where some cultures can be considered as "clashing civilizations" fundamentally incapable of mutual understanding. According to Herzfeld, such conclusions are belied by the experience of intercultural communication, particularly phenomena such as creolization or diasporas (Herzfeld 2005, p. 178). 
dependent on political factors. Klaus Roth takes a similar position, arguing that the models of conflict and segregation are not a rule in South Eastern Europe, but rather the consequence of political events at national level (cf. Roth 2006, p. 21).

In my field research, respondents from both religious groups tend to take pride in their peaceful neighbourly relations, and emphasize their communal ties with neighbours of a different religion. They use phrases such as "we stick together", "they [Muslims - M.L.] are like our people”, “we live like brothers“, “we're all the same”, "our life here together is very good":

Sh.: Our life here together is very good. We're not threatened by events such as those in Bosnia. (M, Interview 38, Leshten 2006)

They [Muslims] are like our people. We are together all the time, there are no divisions or anything like that. We're neighbours. We stick together all the time. (W, Ch, Interview 25, 2005)

In the Rhodopes, the roots of komshuluk as a positive unifying force are religious (this applies to Islam as well as to Christianity) as well as pragmatic (given how the locals are often reliant on assistance from neighbours). This pragmatism is often reinforced by religion, especially in Islam, which puts a special emphasis on the unique relationship with one's neighbour treated as a distinct category of person (similar to Christianity).

Compared with other religions, Muslims tend to believe that Islam fosters a uniquely positive sentiment towards one's neighbours, a belief which they attribute to the Qur'an and numerous statements from the prophet Muhammad arguing that people who have been negligent in their dealings with neighbours cannot hope to enter the Paradise. One of the most popular passages in the Qur'an discussing Good relations between neighbours occurs in verse 36 , Surah 4 containing the words: "Be kind to parents, and the near kinsman, and to orphans, and to the needy, and to the neighb[o]r who is of kin, and to the neighb[o]r who is a stranger, and to the companion at your side, and to the traveller, and to that your right hands own" (4: 36). Muslims as well as Christians compare their neighbours to brothers, and emphasize the key role physical proximity plays in this special relationship: the category of neighbours includes everyone living within the distance of up to forty houses:

Hodzha 1: Above all else, Islam is based on good relations between people. Such relations must be very close. Where it comes to neighbours, Mohammed allay salaam ${ }^{174}$ says that neighbours include everyone within the distance of forty houses to the west, east, north, all those people are neighbours. (Interview 6, Ribnovo 2005)

174 Also pronounced as aley selyam in the local dialect (Arabic: wa-'alayhi al-salam, literally "peace be upon him"). A religious phrase used when mentioning prophets named in the Qur'an, particularly Muhammad. 
Your neighbour is more important than your loved ones. Your neighbour is the person closest to you. When it comes to the worst, your neighbour will come to your aid. Whenever we have a problem, the neighbour is there to help. (W, M, Interview 3, Ribnovo 2005)

Hodzha 2: Your neighbour should be as important as your closest family. You have to respect your neighbour in every way .... Your neighbour is like your brother. The Qur'an actually contains special ayats [Turkish: ayet, Arabic: ayah] about your neighbour and how you should respect him, and so on. (Interview 19, Ribnovo 2005)

Hodzhas often cite the example of the prophet Muhammad and his life, which is also portrayed as the original source of the practice of Good relations between neighbours. In this sense, the duty of good relations derives from the tradition (Sunnah) or the religious duties imposed by Muhammad, and not the farz ${ }^{175}$ (Turkish: farz, Arabic: fard) or the religious duties imposed by Allah himself. At the same time, Muhammad importantly received the teachings about the importance of Good relations between neighbours from the angel Jibra'il/Gabriel (Muslim local variant: Dzhibrail, Turkish: Cebrâil, Arabic: Jibra’il):

Mufti: So, the Angel Dzhibrail came ... He came to the Prophet Muhammad and he went on for a long time about a Muslim's duties towards his neighbours; at one point, Muhammad actually thought... he wouldn't have been surprised to hear that neighbours should have the right of inheritance... [the right] to inherit from one's neighbour. That's how insistent he was about having a good relationship with your neighbour, and so on. (Interview 18, Ribnovo 2005)

To explain the unique importance of good relations between neighbours my respondents often cited those hadiths in which Muhammad shows respect to his neighbours. The most popular passage, cited on numerous occasions, tells the story of Muhammad's concern for a Jewish neighbour who was a real nuisance to the prophet, often leaving his rubbish in the prophet's yard. Muhammad never reproached him; when he came out one day and found no rubbish in front of his house, Muhammad immediately went to visit his neighbour, worried that he might be sick and in need of help. Muhammad's concern impressed his neighbour immensely, and he made a deathbed conversion to Islam:

Hodzha 3: The Prophet himself practised this. The Prophet had a neighbour, a Jew who used to put rubbish in Muhammad's yard when he wasn't home. One day the Prophet was astonished to see no rubbish, and he concluded that his neighbour must be ill. He went to pay him a visit, to see his neighbour. The neighbour asked him, “How did you know I was not well?” He answered: "Every day you leave your rubbish in my yard, but I saw no rubbish today. I guessed you must be ill, so I came to see you.” This is why [Muhammad's neighbour - M.L.] later converted to Islam. (Interview 17, Ribnovo 2005)

175 Religious duties imposed by Allah which; keeping those duties beings rewards, and dereliction is punished. 
Examples from the life of the prophet Muhammad encapsulate the Muslim duty to show respect to your neighbour regardless of his religion.

When asked about their attitudes towards their neighbours, Muslims also highlight the soteriological aspects of good relations since the dealings with one's neighbour are part of the partial judgement over the soul of a deceased person which takes place in the grave, and involves a series of questions relating to one's life. The questions are posed by two angels named Munkar and Nakir ${ }^{176}$ :

S.: They say that when you move on to the next world, the first thing [the angels - M.L.] ask you about your relationship with your neighbour. (W, M, Interview 2, Ribnovo 2005)

Hodzha 4: A Muslim must have the best of relationships with his neighbour, that's the first thing you get asked there [by the angels during the partial judgement in the grave - M.L.]: how about your neighbour, what was your relationship with your neighbour. That's because your neighbour lives closest to you. If you hate your neighbour you get punished there. (Interview 3, Ribnovo 2005)

Good deeds performed in order to win salvation in the next world are called sevap ${ }^{177}$ (Turkish: sewap, Arabic: sawab) by Muslims.

The Christians likewise recognize good relations between neighbours as an intrinsically positive thing and provide numerous examples to that effect, however they are much less likely to invoke religious narratives. I encountered one exception, a comment made by the Archimandrite of Hadzhidimovo:

Archimandrite Grigoriy: Neighbourly love is a duty, despite the fact that they are Muslims. When you see a Muslim's house on fire you have to put out the flames. You see him carrying timbers, you help him out, isn't that right? It's all about the commandment to love your neighbour, to love God and to love your neighbour as you love yourself. If we observe God's commandments we're never going to insult or injure a Muslim neighbour, quite the opposite. (Interview 27, 2005)

Christians tend to interpret the good relations with their Muslim neighbours in terms of affection and friendship rather than religious injunctions:

K.: Personally, I have a lot of Muslim friends. I don't know if my mum told you that but I was born in Syrnitsa, which is predominantly Muslim. We've had Muslim friends in our family for a long time, ever since I can remember, and we felt they were as close to us as other Christians. They would come and visit us. My mum says they were really close to them, like parents. They helped her because she was alone. As long as I can remember we've had Christian friends and Muslim friends. (W, M, Interview 37, Garmen 2006)

The narrative of good relations between neighbours is corroborated by the mutual help and assistance practiced by respondents in their daily life, an instance of the

176 For more information on the Muslim belief in the partial judgement taking place in the grave see (Lubanska 2005).

177 A good deed. 
famous Maussian principle do ut des confirmed daily through a series of routine and ritual neighbourly obligations; as a result, there is a need for symmetry in their mutual dealings.

For the local religiously heterogeneous community, ritual exchanges are a way of making their peaceful intentions known through messages confirming that both groups may rely on each other's help in daily life in tasks such as unloading hay, sharing of medicine, keeping a cow in your neighbour's cow shed, etc:

V.: We help each other. They [the Muslims - M.L.] help me a lot and I'm very happy with those people. They helped me whenever I need it. I help them and they helped me.

M.L.: Could you give me any examples?

V.: For instance, when I bring the hay in and can't unload it, they come and help me. (W, Ch, Interview 11, Osikovo 2005)

Ritual exchanges of favors also take place as part of an individual's life cycle, from birth, when close female neighbours visit the mother and child several days after the delivery and bring food ${ }^{178}$ (ponuda), until death, when non-coreligionist neighbours attend funerals or wakes in the deceased person's home. Such rituals are so important to my respondents that they are prepared to bend the rules of their own religion in performing them:

M.L.: And you come to each other's funerals?

F.: We do. Not all of us, but we do.

A.: Religion forbids it, but we come all the same.

F.: We live here together, and you simply have to be there.

A.: Out of respect for the person.

F.: We do, we definitely do....

A.: For instance, when a [female] neighbour who's a friend dies, we'll spend the whole night sitting there.

F.: Religion forbids it but people [expect it - M.L.]...

178 Including, among others, banitsa, a popular food in the Balkans made of thin layers of pastry (Bulgarian: kori, Greek: filo) layered with savoury filling, e.g. salty white cheese and oil and often formed into a spiral shape, pilaf (rice cooked with meat and vegetables), pears, apples and kachamak (corn porridge cooked and baked with salty cheese) (cf. Tsaneva 1994, p. 135). 
A.: We're all people after all. What is religion, what kind of barrier is that, honestly?! How could I not come?! Of course I would!

M.L.: You don't come to the church but you do come to the cemetery, right?

F.: No, not to the cemetery, to the house.

A.: Oh yes! We go, to light a candle. For instance, when my husband died my neighbour spent the whole night sitting here. She spent the whole night here! Everybody comes to a burial, no matter if they're Bulgarian or Muslim!

F.: In these parts when a Christian dies, that Christian has a lot of Muslim friends. And the other way around, Muslims have Christian friends.

A.: They eat with one spoon.

F.: And the other way around, when a Muslim dies, they will have Christian friends. And they all come as well. (W, M, Interview 24, 2005)

It might be worth citing Marcel Mauss's observation that such relations of mutuality, though outwardly voluntary, are in fact obligatory, and neglecting them threatens "private or open warfare" (Mauss 1966, p. 3). Some of my respondents have made comments to that effect:

Hodzha 5: As a rule, every religion needs to be tolerant towards others.

M.L.: How exactly is that tolerance expressed?

H.A.: They shouldn't be snubbed. Say, a Muslim makes banitsa or baklava ${ }^{179}$ and takes some to share with a neighbour who's Christian or Jewish, or whatever. If that neighbour does not accept it, they will feel unwanted. And you get an atmosphere of intolerance, something like hatred. But if you accept the gift, then you get an affinity between them, like between good neighbours. And you get mutual understanding, as required by Islam, rather than enmity or hatred. (Interview 26, 2005)

Apparently, the respondent realises that good relations between neighbours produce an affinity between people, whereas disruptions to the symmetries of komshuluk may provoke an immediate reaction from the slighted group. As a result, the principle of reciprocity which regulates the relations of the two religious groups may lead to a situation where each group is making a point of retaining a distinctive identity, increasingly presented in opposition to the lifestyle represented by the neighbour of a different religious faith.

When neighbours no longer exchange gifts, visit each other at important times in their lives or greet each other in the street, the neighbourly relations become less

179 A different type of kori pastry with a sweet filling consisting of nuts and syrup. 
predictable and transparent. When both religious groups care to preserve the peaceful relationship they need a way of communicating this intention, a role played by the relationships of reciprocity, which is in turn postulated and upheld by the narratives of good relations between neighbours.

Positive relations between neighbours are a good which the local community aspires to in spite of the historical ressentiment existing between the two groups, and despite the fears that such relations might prove very fragile. Although good neighbourly relations have suffered ruptures as a result of traumatic historical events, they have always been restored. ${ }^{180}$

At the same time, both sides realize that participation in the religious practice of neighbours belonging to different religions serves no other purpose than to affirm the good relations between neighbours between them, and not to actually adopt it. Consequently, such participation in ritual is partial and does not extend to any rituals held in churches or mosques, respectively, or at the actual graveside:

Hodzha 1: I lived in Pletena as an imam, and we had a few funerals in Satovcha. And when that moment came [i.e. when the funeral procession reached the gates of the cemetery - M.L.], they would split. They come with the dead person to that place, and then they part ways, because they believe that this is something they cannot do, that would bring them closer to us, make them like us. (Interview 10, Ribnovo 2005)

The relationship of reciprocity also includes practices such as exchanges of gifts and festive foods, mutual help of visits during important life events (childbirth, marriage, burial).

Such practices take place within the framework of the annual cycle of religious holidays. Muslims often offer meat and sweets to the Christian neighbours on the Muslim feast of Kurban Bayram (Feast of Sacrifice, Turkish: Kurban Bayram1 ${ }^{181}$, Arabic: 'Id al-Adha):

180 Evidence of the revival of ritual exchanges of food in Bulgaria after the repressions of the Zhivkov era ended.

181 Sunni Muslims celebrate two holidays, Ramazan Bayram and Kurban Bayram, which are 70 days apart. In the month before Ramadan Bayram Muslims fast during the daytime abstaining from eating, drinking and smoking. Ramadan Bayram celebrations last for 3-4 days, with traditional foods such as banitsa, kachamak or baklava. Family members traditionally visit each other at this time. Kurban Bayram, the most important holiday in the Muslim calendar, lasts about a week. A white and unblemished lamb under six months of age is sacrificed in every home. Before the sacrifice, a hodzha reads a prayer over the lamb and covers the animal's head with a kerchief in commemoration of the gesture traditionally believed to have been made by Ibrahim over Isma'il. The lamb is often named after a living or deceased relative (in the former case the animal is killed on the first day of the holiday, in the latter - on the eve of the holiday. The blood of the animal gets collected into a vessel and buried in a hole in the ground. The blood is believed to have healing powers and some older women keep it for medicinal purposes (cf. Popov 1994, p. 115). 
A.: Gergana is Christian. She's my friend. I come to her birthday, I greet her ${ }^{182}$ at Easter and Christmas. She brings me sweets, I do the same for them during Bayram. (W, M, Interview 24, 2005)

Sh.: We live in Ognianovo, which likewise a mixed village. We don't treat our neighbours any different. How could you ignore a neighbour? During their holidays, Easter, they offer us lemonade. (W, M, Interview 2, Ribnovo 2005)

D.: We celebrate. When they are celebrating Bayram we visit them and they offer food to us. And during Easter we offer them eggs. We celebrate together. (W, Ch, Interview 38, Leshten 2006)

\section{At Easter, Orthodox Christians offer Easter cake and red eggs to Muslims:}

G.: You absolutely have to offer things to your neighbour, no question about it. Leave a neighbour out, and it doesn't count. That's what they say. It's like not having shared at all. It will have no effect. (W, Ch, Interview 23, 2005)

Both groups offer each other food during holidays dedicated to remembering the dead: orthodox Christian: Zadushnitsa, Muslim: Arfe ${ }^{183}$ (Turkish: Arefe or Arife, Arabic: 'Arafah):

S.: We have Arfe, that's what it's called. You hold an Arfe before each Bayram. I give food out to neighbours, people who are close to you. For two days you prepare the foods at home, and then you give out mekŭtsi ${ }^{184}$ and halva. (W, M, Interview 2, Ribnovo 2005)

When offered food during the Muslim holiday of Arfe, Christians thank them using secular phrases, such as Chestit praznik ("Best holiday wishes") or Blagodarya. Zhivi $i$ zdravi da ste. Do godina pak da ni cherpite! ("Thank you. May you be alive and well, and offer us more next year!”). Muslims do the same when offered food by Christians:

M.: They hold their celebrations for the dead (Odusha, Zadushnitsa) ${ }^{185}$, [which they call - M.L.] Arfe. And they bring us mekŭtsi, banitsi, a little bag of everything. That whole part of the village that's close to us, they will bring something to offer us.

182 Greeting neighbours in the street is another important element of the komshuluk system. Popular greeting may say things like, “Welcome! Where are you going?”. The reply is, “Just taking a walk.” My respondents complained about the influx of new inhabitants, who neglect to properly engage in this social ritual.

183 The ninth day of the month of pilgrimage, believed to be the day of the remission of sins. On that day pilgrims gather on Mount Arafat, ca. $20 \mathrm{~km}$ from Mecca. In this context, It seems symbolic that the pronunciation of the name for that practice is similar to the Arabic word Al-A'raf (literally, "raised edges"), meaning something like Purgatory in Islam. On that day Muslims in the Rhodopes believe they can help souls awaiting judgement by sharing food (mekŭtsi, sweets) with neighbours. They use the term as an equivalent for the Orthodox Christian holiday of All Souls' Day, which they celebrate not only during the Hajj but also two days before Ramadan Bayram.

184 A dish made of deep-fried yeast dough powdered with icing sugar.

185 In the Orthodox Church, All Souls' Day is held on the Saturday before the Meat Lent Sunday 
M.L.: When you accept the things they offer, is there a special thing you say?

M.: We say it our way: Da ste zhivi i zdravi [May you be alive and well], may your house be always full, so you can share food with us again.

M.L.: When is Arfe, when do they hold it?

S.: At two points during the year we have our holidays, Christmas and Easter. They have Bayrams twice a year. One of those is Ramazan Bayram, the other is Kurban Bayram. They hold it before each.

M.L.: Arfe falls before each of those holidays?

S.: Yes. (W, Ch, Interview 34, Garmen 2006)

B.: I have a friend from Debren who used to invite me to come and visit her during Bayram. We went to visit. That's because we have friends from neighbouring villages, Muslims. They invite us over for their holidays, and we invite them over for Easter. On those occasions they make famous mekŭtsi. One day before Bayram they have a day for the dead. That's when they make those mekŭtsi. Arfe, I'm not quite sure what it's called. And they offer us the mekŭtsi here. Many of them work in Garmen and they bring it in bags and offer it to us. Just like we bring them Easter eggs and kozunatsi [Easter yeast cakes].

M.L.: When you share the kozunatsi, are there any special words you say?

B.: Chestit praznik.

M.L.: And when they accept it?

B.: They say the same. (W, Ch, Interview 51, Garmen 2006)

Similarly, when neighbours meet in the street during a religious holiday, Christian or Muslim, they also greet each other with the neutral phrase Chesti praznik. Specifically religious greetings, though familiar to members of each group, are not used. When uttered, religious phrases are often associated with certain gestures ${ }^{186}$ which might lead to assimilation, an undesirable outcome for each of the groups.

Importantly, the respondents realize that such food sharing practices are subject to certain restrictions and must be done with tact to spare the other group's religious sensibilities. Christians believe it would be inappropriate to offer Muslims foods such

(mesopustna), the Saturday before Pentecost, the Saturday before the Feast of St. Michael the Archangel; the Muslim Small and Great Arfe is held two days before the Bayrams (one day before according to Christians).

186 At Ramazan Bayram exchange greetings while shaking with the person opposite. Younger people kiss the hands of their elders, who give them money (a practice called "giving a bayram"). 
as kolivo (sweet boiled grain) ${ }^{187}$, which is given out as part of a religious practice performed for the dead, alcohol or pork:

M.L.: When they come to visit, you don't serve them pork?

S.: No, they know I would never serve pork to them. How could I take that sin on myself? That's just right. (Interview 35, Garmen 2006)

M.L.: So, what kind of food do you offer them?

V.: according to our tradition it has to be wheat, wine, but I never offer them wine or wheat [kolivo - M.L.]. I bring them sweets, kiflichki (crescent-shaped pastries), kolachite, as we call them. And they offer the same to me. There is a day when they celebrate Arfeto. When that happens, one day it is celebrated for the dead, and on the other day they celebrated for their living. They offer me food. For the living, they give banitsa, cakes, I don’t know what else. (W, Ch, Interview 11, Osikovo 2005)

Far from being permanent, the rules of reciprocity are subject to constant modification. For instance, Christians, when they notice increased orthodox religiosity in their neighbours, are not always sure what kind of gift will be acceptable. One of my respondents before offering Easter eggs to her Muslim neighbours tried to find out whether or not her neighbours would be committing a sin in accepting them:

G.: As a general rule, after painting the eggs I bring them to them [i.e. friends from a Muslim family - M.L.]. In fact, I recently asked them, I noticed they'd started to practice more, they're bowing [in prayer - M.L.] and do all those things that are required in their religion. They didn't use to do that until recently, so now I felt very awkward, bringing the eggs to them, because I didn't know if that would be a sin for them. So I asked them: "If it's a sin, I will not bring the food to share with you. I won't be offended, if you can't accept it just tell me." - "It's not a problem at all. It wasn't us who painted the eggs. They make us happy. The children will knock them together until they break, to see whose egg is the toughest, and they'll eat them. No problem at all. We didn’t paint those eggs, and it won’t be us eating them.” (W, Ch, Interview 23, 2005)

I did not come across similar scruples in conversations with my Muslim respondents. This is probably because for Christians the problem of ritual impurity in foods only arises during times of fasting (when all animal products become impure).

Children seem to play an important role in the ritual offering a food between the two religious groups. Often it is the children in the family who offer and receive the food exchanged between neighbours practising different religions. This may also stem from the fact that adults tend to be busy on festive occasions and simply ask the children to do more errands for them:

187 Christians believe that this might be inappropriate partly because this food is traditionally shared in churches after a panikhida (an Orthodox Christian memorial service), which Muslims do not attend. 
M.L.: You said you offered food to Muslims, but how do you do that? Leshten is not mixed, is it? Does that mean you bring food to offer it to people in other villages, such as Gorno Drianovo?

D.: Well, it's Easter. We paint eggs. People from the other villages send their children to us as well, and we give them eggs, banitsas, yeast cake. (W, Ch, Interview 38, Leshten 2006)

Also, as indicated before, practices which might lead to religious syncretism (such as the knocking game played with the Easter eggs) are relegated to the children. This way they can be interpreted as play and not as a symptom of religious assimilation. Donations towards the building of places of religious cult (Orthodox churches or mosques) are another way of emphasizing good relations between the groups. In the case of Islam's, a donation for a sacred building is known as a waqf (local Muslim variant vakŭf, Turkish: vakıf, Arabic: waqf). One of the hodzhas emphasized the importance of waqfs during the period of Ottoman rule in Bulgaria, pointing out that Turkish sultans and beys would often erect Christian temples as a gift for the Christian ra'iyyah (local Muslim variant: raya Turkish: reaya, Arabic: ra'iyah) ${ }^{188}$, frequently at the encouragement of their Christian wives:

Hodzha 1: Turkey is a state, Bulgaria spent 500 years under Turkish occupation, but what did Turkey do, what did it leave in Bulgaria in terms of historical monuments? All the Orthodox churches in Sofia and even beyond, in the provinces, including the monasteries built at the time, all that was built during Turkish occupation. I can even tell you about a certain fact. The Orthodox church in Bansko, that large church next to the road, those frescoes [in the church - M.L.] were financed by the Sultan. Not the Sultan, but the bey, as a gift to the Christians in Bansko! There were never any Turks [living] in that place. (Interview 10, Ribnovo 2005)

The hodzha went on to list the most important Christian sacred buildings in Bulgaria arguing that they were funded by the Turkish state as gifts:

Hodzha 1: The rich Turks held Bulgaria under Ottoman yoke for 500 years, but don't forget the good things they did. Such is the monasteries in the Rila monastery, Bachkovo monastery, the Church of St. Nedelya in the brown in Sofia and other churches. And in Rila monastery... Do you know the story of the monastery in Rila? ... It was built by a certain Turkish bey as a testament of his love for a very pretty Bulgarian girl. She agreed to marry him on the condition that he would build the monastery. (Interview 10, Ribnovo 2005)

Donations made to the sacred buildings of the other religious group must be seen as an element of the komshuluk, and not as signs of appreciation for the other religion as they entail no interest in treating the other religion as an alternative road to salvation.

188 Literally, "the herd”: non-Muslim taxpayers in the Ottoman Empire. 


\subsection{The Limits of Komshuluk}

The line separating religious syncretism, on the one hand, from simple respect shown to neighbours form a different religious group, on the other, by participating in their rituals, is mostly a matter of interest to the religious elites (particularly Islamic). The Islamic elites often interpret this borderline as fluid, which provokes concerns over potential assimilation, and leads to imposing limitations on the dealings between the Muslim population and the Christian neighbours. Shurfe, a local woman who accompanied me in my field research in Ribnovo in 2005, actually volunteered to query the hodzhas about the limits of good-neighbourly relations. During the conversations with two hodzhas she asked if she was allowed to light a candle by the body of a deceased Christian neighbour or hold wake in the house of her Christian neighbours. The hodzhas again invoked the example of the prophet Muhammad to explain that such practices were not acceptable. Showing respect to a neighbour from a different religion should be limited to a single subtle gesture and not involve participating in the rituals of another religion:

\footnotetext{
Woman Sh.: Since we're talking about holidays, can I ask you a question? For instance, when I go to the funeral of a Christian who died... They have those candles, and they light them. So, if a light a candle, is that a sin?
}

Hodzha 3: We're not allowed to do that. But there is this well-known story of the Prophet where
a funeral procession was passing by and he stopped. And the Muslims who were with him said,
"But that's a Jew". He said to them, “That doesn't matter. We have to respect his funeral”. That
means he has respect [for a member of a different religion - M.L.]. But in Islam, lighting candles
may be considered as a bit of shirk ${ }^{189}$ or idolatry. Because that's part of the Christian ritual and
religion. And we shouldn't become like Christians. (Interview 17, Ribnovo 2005)

Hodzha 1: I mean, if you light a candle to show respect for that person, then as a matter of principle the lighting of a candle is something that is not done in Islam, so you're doing something that's done by another religion. And that's haram - that which is forbidden and punished, a religious transgression, sin - M.L.], something that mustn't be done. But if you pray for that person your own way, as allowed by your own religion, then that's no problem. (Interview 10, Ribnovo 2005)

In this statement, the anti-syncretic attitude is presented as a better way of ensuring a continuation of the status quo and maintaining peaceful interreligious relations than outward imitation of neighbours professing a different religion. The hodzha's words are a clear example of the anti-syncretic thinking discussed in Chapter 2, where a term such as "mixed" is seen as a threat to authentic faith. This does not apply to situations where a Muslim prays the Muslim way in a Christian place of cult, but it does

189 Idolatry, the most serious sin in Islam. 
apply when elements of a different cult become introduced into one's own religion. The argument is that religious synthesis may lead to a crisis in the community. This theory is reminiscent of Girard's interpretation of sacrificial crisis in which reactions by members of communities-in-encounters are similar to the point of becoming indistinguishable (Girard 1986).

The hodzhas perceive a dual threat to Muslims: one is the risk of temptation posed by a proselytizing Christian neighbour; the other is connected with a visit to a neighbour's house, which may pose risks of ritual impurity because a Muslim cannot be sure whether or not the meal offered by the neighbour contains forbidden foodstuffs, such as pork:

Hodzha 1: You can help your neighbour when they fall on hard times, you can talk to them, you can eat together, but then again, that will depend on the kind of food as there are certain requirements...

M.L.: Meaning, you shouldn’t eat pork?

H.1: Precisely. There are many other ways of acceptable coexistence, of living together. But you must on no account do more important things which would be acceptable in the case of a fellow Muslim. For instance, if they start inviting you [on a more regular basis - M.L.]. This is a problem that I discussed in the mosque a few minutes ago. If they say, "leave your God and come to me. Forsake your faith", especially if the person is a non-believer [nevernik], and they say, "Be like me". I mean, you mustn't follow him. When that happens you have to break off those ties. (Interview 6, Ribnovo 2005)

As suggested by this comment, the ties of affection between neighbours practising different religions may be severed as soon as they start posing a threat to religious orthodoxy. In the case of a conflict of interest, a Muslim must give priority to their own religion, family and fellow Muslims, and the needs of their non-Muslim neighbour must come second.

Hodzha 1: When your neighbour is in need... I mean, when he needs help, then help him in every way you can. But you should on no account treat him as more important than your parent or a fellow Muslim. (Interview 9, Ribnovo 2005)

For the Muslims, priority is given to neighbours who are also relatives, followed by Muslim neighbours, followed by non-Muslim neighbours. This rule seems to stem from the Qur'anic passage cited above (Surah 4 verse 36):

Hodzha 1: There are three types of neighbours: neighbours who are your kin, neighbours who are Muslims but are not your relatives, and non-Muslim neighbours. Mahomet alehis salyam says that we are bound by three obligations towards a Muslim who is a relative, two obligations towards a Muslim who is not a relative, and one towards a neighbour who is not a Muslim. (Interview 6, Ribnovo 2005) 
F.: If your neighbour is a relative you have three obligations towards him. Treat him even better, help him with his work. Don’t ignore his needs. Help him out.

M.L.: What about neighbours of a different faith? Do you have the same obligations towards him, or maybe not as many?

F.: Yes. There are obligations. Those are religious obligations to help him, and to treat him well. (Interview 16, Ribnovo 2005)

My respondents were unable to explain precisely the difference between a Muslim's obligations towards a neighbour who is a co-religionist and a neighbour who is a nonMuslim. It seems that the exact differences in terms of neighbourly duties between Muslim and non-Muslim neighbours are decided by each of the respondents on a case-by-case basis. All my respondents agreed that one's obligations towards fellow Muslims were greater but the specifics didn't seem to overlap. The different number of obligations should be treated as symbolic, indicating more care without identifying precisely what the difference might be.

In addition to reciprocity, Good relations between neighbours also involve other elements, such as steering clear of religious topics in conversations held by members of different religious groups:

F2: Those are topics you avoid.

M.L.: Meaning, you don't talk about those things?

F2: No, we don't, because we assume that Muslims and Christians may be friends without mixing their religions.

A: Let every frog stick to its own puddle. (W, M, Interview 24, Satovcha 2005)

At the same time, regular people tend to believe that good relations between neighbours represent an overarching good which cannot be threatened by religious cult, no matter how fervent or invasive in terms of daily habits:

G.: And they say, "No matter how hard we try to observe those religions or comply with the canons imposed by them, and no matter how different those canons might be, we must not grow apart. We'll stay united, and our mutual relations will remain unchanged." It doesn't matter that until yesterday my friend didn't use to rush out and leave at 1:30 to go pray and make bows, right? That now she can't be with me at 1:30. I simply adapt, and when we go out we leave the place together. (Interview 23, Satovcha 2005)

My respondents emphasized the need to remain separate with sayings such as the one quoted above, "Let every frog stick to its own puddle”, meaning "Everybody minds their own business and we generally live like good neighbours", "We are separated by a single skin of an onion”. The Muslims seem more intent on preserving the religious 
boundaries, especially if involved with "Salafi Islam", which is more anti-syncretic than "Adat Islam".

Both groups realise that their differences are religious, and therefore find it safer to keep to themselves any opinions they might have about their neighbours' religion when talking to them. This is understandable in a situation where both groups tend to exclude the other group from the community of the saved in the next world.

Importantly, each group knows offensive, derogatory terms for the other. The Christians may refer to Muslims as "Pomaks" (pronounced in a contemptuous tone). The Muslims may refer to Christians as giaurs (Muslim local variant kyaur, Turkish: gâvur, Arabic: kafir) - meaning infidels:

M.L.: What kind of words do they use when they mean to insult you?

G.: They call us kyauri. That's offensive.

M.L.: Kyauri?

G.: Kyauri. It's a kind of comeback. And it's enough to slight us...

M.L.: Meaning, they use the word kyaur around here?

G.: Kyaur. That's derived from giaour, and that's what they say it here in Satovcha.

M.L.: In what sense?

G.: In a negative sense. The meaning is pejorative. Not good. For a positive word, a positive meaning, they would call you a Bulgarian, a Christian. (W, Ch, Interview 23, 2005)

S.: The Turkish word kyaur is essentially the same thing as Bulgarian. (W, Ch, Interview 35, Garmen 2006)

Another symptom of the isolationist attitude is the small number of mixed marriages ${ }^{190}$. The community accepts the mixed marriages in the community ${ }^{191}$ but such unions are by and large not accepted by the families of the spouses, who often perceive their marriage as sinful. The Muslims believe it is sinful for a Muslim woman to marry a Christian man:

M.L.: Why is it sinful for a Muslim woman to marry a Christian?

F.: Allah gave us dzhehendem [Turkish: cehennem, Arabic: jahannam - hell - M.L.] and dzhehennet [Turkish: cennet, Arabic: jannah - paradise, heaven - M.L.] When one of our girls takes a Bulgarian husband, she will go to their, you know, to dzhehendem. But if she loves Allah

190 For instance, in Satovcha, where I did my field research, there were six.

191 Burials are problematic as it is not clear which cemetery should be used. 
and feels some remorse, than she might go to dzhehennet. That's why it's a sin. It's the same thing for your girls marrying our bachelors. Except they are lucky. They will go to paradise. If she turns Turk, if she turns Turk she goes to paradise .... But then again, Musa, a different hodzha, says that a Muslim girl who marries a Bulgarian, if she marries a Bulgarian, than she will burn in the flames in the next world. She will stand in flames from here to here [the respondent makes a head-to-toe gesture] to burn that sin away. (W, M, Interview 12, Ribnovo 2005)

There were instances in the respondent's family of a Christian woman ${ }^{192}$ who "gave up her faith" and changed her name to marry a Muslim man (she chose the name of her mother-in-law, Rafuz), and of a Muslim girl, the daughter of the respondent's cousin, who married a student enrolled in a Christian seminary school and changed her name from Ramze to Ereni. Several respondents mentioned the former example to me on various occasions, clearly taking pride in the fact. They remarked on how the woman was prepared to give up everything to become united with the man she chose. They emphasized the fact that the woman changed her name, wore their traditional clothes, observed her fasts and was more religious than some of the local women, and above all they pointed out that she had ensured salvation for herself:

F.: If she wanted to have a pretty fiancé... She liked a boy, but his mother wouldn’t let him. And she said: "I'm going to give up my name and everything". And now she's changed her name to Rafuz. And she is very pretty and very good. Oh, that is going to work in her favor.

M.L.: And she became Muslim straight away?

F.: Yes, as soon as her husband brought her here and they wrote down the name. She chose her name. And she chose the name of Rafuz, her mother-in-law. And the hodzhas says that it's not a sin when a Muslim man takes a Christian woman. He may convert her, turned her Turk. But if one of our girls takes a Bulgarian, he can’t turn her Turk. (W, M, Interview 23, Ribnovo 2005)

D.: My daughter-in-law's aunt lived in Ognianovo, she married a Pomak. As children they were neighbours and they fancied each other. They graduated from high school and university, and they got married. They're living in Blagoevgrad now ... Love knows no boundaries. (W, $\mathrm{Ch}$, Interview 41, Garmen 2006)

In general, my respondents took a tolerant view of mixed marriages, saying like this respondent that "love knows no boundaries". But as a rule they would not be happy to see their own children marry outside of their faith:

F2: We may be attracted to each other, we may be friends and have plans together, but when it comes to religion, it's something internal that's given to you.

A.: Please, I forbid my daughter to marry a Bulgarian. I am absolutely opposed. That would be a huge mistake. I cannot allow a Muslim girl to become a Christian. No way. That's the biggest mistake. Or for you to find a Muslim man. No. (W, M, Interview 24, 2005)

192 The couple live in the village of Musovishte, which I did not manage to reach. 
According to my respondents, such marriages are made difficult by the sensitive family situation where both families have concerns related to their salvation and their reputation in the community. Disappointingly, my repeated attempts to reach such converts were unsuccessful. For various reasons interviews proved impossible to arrange, possibly not entirely by accident. I had the sense that my respondents were reluctant to introduce the converts to me in order to safeguard their privacy and peace of mind.

In Garmen, different respondents on two different occasions shared a disturbing story of mob justice meted out by the inhabitants of Garmen upon an Orthodox priest whose daughter married a Turkish officer during the Ottoman rule:

I.: And then some Turks arrived here in Garmen. A certain priest, we call him Georgi Shamanov, had a daughter. And she fell in love with a certain Turk, well, not so much fell in love as was raped, and he took her to his house, and she turned Turk. When they settled down in Debren, she lived with him, they had children. But her father met his judgment here for allowing his daughter to elope with a Turk. They asked him..., there's a place around here called St. Ilya. They asked him to hold a funeral service there, which he did. They'd dug a grave, and they threw him in the grave and buried him alive for letting her daughter marry a Turk. (M, Ch, Interview 40, Garmen 2006)

Attitudes towards mixed marriages probably change depending on historical circumstances. Peacetime marriages (in an independent state) are usually interpreted by the public as love marriages, whereas marriages in turbulent times may be interpreted as treasonous and opportunistic.

\subsection{The Ressentiment Narrative}

According to Max Scheler, ressentiment arises when powerful emotions "must be suppressed because they are coupled with the feeling that one is unable to act them out-either because of weakness, physical or mental, or because of fear. Through its very origin, ressentiment is therefore chiefly confined to those who serve and are dominated at the moment, who fruitlessly resent the sting of authority" (Scheler 1998 [2010], p. 6). "Thirst for revenge," Scheler argues, "is the most important source of ressentiment" (Scheler 1998 [2010], p. 5). Although I believe the term "ressentiment narrative" is warranted in the context of my research, this is not to argue that this sentiment underlies the relations between my Muslim and Christian respondents: it would be a mistake to analyze those relations without taking into account their good relations, just as it would be a mistake to analyze good neighbourly relations without realizing the mutual fears harbored by Christians and Muslims. Accordingly, the category of ambivalence seems key to understanding the mutual relationship.

In contrast to the narrative of good relations, the ressentiment narrative is "endogamous" and only reluctantly revealed to outsiders. It mainly consists of topics 
and problems usually kept out of conversations with non-coreligionists. In contrast to the strategies for preferred patterns of coexistence, it reveals mutual fears about what the non-coreligionist neighbours might do if and when they achieved political or demographic dominance.

Although both the groups are indigenous, this enduring sense of ressentiment reflects the continued existence of contradictory memories of the past. Orthodox Christians preserve memories of forced conversion to Islam and the betrayal of Bulgarian-speaking Muslims, whereas the Bulgarian-speaking Muslim community preserves the memory of forced assimilation. Notably, the symbols actualized in ressentiment narratives are remarkably similar in both groups and have folk origins. Bulgarian national martyrology is based on folk motifs, such as chained victims (the subject of a folk song about Prince Marko), the yoke of repression or massacres. It portrays non-coreligionist neighbours as unpredictable potential aggressors, rather than the peaceful brothers portrayed in the public narratives.

Such narratives reflect the continued memory of past conflicts, implying that the conflicts might re-emerge cyclically if trust between the two groups were to erode. Often, the noumenal ${ }^{193}$ nature of the events which triggered the ressentiment remains irresolvable as actual events blend with historical myth. Although the respondents identify the source of their narratives as oral transmission received from the elders, the narratives in structural terms seem to be colored by ideology and shaped by national martyrology. This particularly applies to a Christian narrative I heard in from a group of elderly Christian women (see below). However, there are many analogies between this and the parallel narrative told by Muslims. In both cases we are dealing with religiously homogenous groups. The Christians ${ }^{194}$ mentioned the massacre in Batak $^{195}$ (1876) as an example of mutual conflicts which "very nearly" occurred in Satovcha:

Woman 1: Now listen, there was a time when they were sharpening their knives to turn against us. We had [in this house - M.L.] an old woman, a relative. She told me that. They were sharpening their knives over there, we're telling you, there used to be stones there, and willow trees... And the Turks were sharpening their knives because they wanted to come here and make a massacre, to massacre our village. But...

193 I borrow this term from Ankersmit 2004, p. 382.

194 So long as there was a Muslim woman in the company the Christian respondents were telling me about the close ties and peaceful relations between neighbours. When the Muslim woman left, they changed the topic to the massacre in Batak and their fears.

195 This is a reference to a massacre of the Christian population of Batak at the hands of Bulgarianspeaking Muslims from the village of Barutin. Some of the victims were women and children who fled to a church for safety. The skulls of the victims kept in Batak are considered by Bulgarians to be national relics. For more information see Batak... 2007. 
Woman 2: Right, but they went to Batak instead, to massacre people [there]. If you went there you would see those things. Little hands and everything, they massacred tiny babies. They closed the church, and massacred all the people with knives.

Woman 1: The church, the Turks closed the church and they would [kill] little children, men, women, everybody. There was blood in the yard and tiny heads... (W, Ch, Interview 25, 2005)

The connection which the old women made with the Batak massacre is unsurprising. The Batak massacre holds an important place in the Bulgarian collective memory (Baleva, Brunnbauer 2007, p. 5.) which "is not static or clear-cut; the process is subject to being updated and transformed as a result of historical change"196 (Troeva 2007, p. 125, translated from Bulgarian). Batak is described as a "site of extermination", "a shrine" (Zahari Stoianov), or "the Bulgarian Golgotha" (Ivan Vazov) (cited in: Troeva 2007, p. 128). "Tens of thousands of people” visit the museum in Batak every day (Brunnbauer 2007, p. 91).

In the past, a painting entitled "The Massacre in Batak" (1893) by Antoni Piotrowski, a Polish painter, was treated as a reliable historical source, lending the event historical credibility alongside photographs by Dimitar Kavra's entitled ${ }^{197}$ "Survivors of the Batak Massacre" (1876) and “The Historic Church After the Massacre in Batak (undated). Piotrowski's painting played a major role in the shaping of Bulgarian national martyrology, and was frequently reproduced in Bulgarian history and literature textbooks, which did not mention the fact that the painting was in fact a reenactment created by the painter, and could not be treated as legitimate historical evidence, a fact which got quickly forgotten (Baleva, Brunnbauer 2007, p. 5-6). According to Baleva and Brunnbauer, the painting was inspired by the reporting of MacGahan, an American who was a Daily News reporter, published in 1876.

Similar doubts have arisen about Dimitar Kavra's photographs. Recent research suggests that Kavra's two photographs were likewise staged reconstructions of the massacre, commissioned by Antoni Piotrowski, the Polish painter, who used them in his work on the painting. Recently, new findings have pushed the dating of the two photographs, which are currently believed to have been made between 1886 and 1888), and the original titles have come to light: the first photograph used to be called "A Reconstruction of the Massacre in Front of the School in Batak", the second "An Exhibition of the Mortal Remains in the Church of St. Nedelya in Batak" (for more on that topic see: Baleva, Brunnbauer 2007, p. 15-32). It should be added that those new findings did not meet with much enthusiasm among the self-appointed custodians of collective Bulgarian memory in the historical profession (Troeva 2007, p. 125).

196 This problem was tackled in a well-known and controversial Bulgarian-German research project, Istoriya na sŭvremie i natsyonalni stereotipi $v$ Bŭlgariya $v$ svetlinata na mita za Batak, headed by M. Baleva and U. Brunnbauer. For more information about the reaction to this project from various segments of Bulgarian society see G. Szwat-Gyłybowa (2009).

197 Formerly the photographs dated to the period of 1876-1878. 
The massacre in Batak is an important locus in this collective memory, shaping the collective imagination of Ottoman occupation (Szwat-Gyłybowa 2009, p. 8).

The image of the Turk/Muslim/convert as a bloody henchman inflicting violence on Bulgarians, particularly Bulgarian women and children, was a frequent motif in the Christian narratives I encountered in the field:

S.: The Turks were very evil. When they got hold of a woman, a Bulgarian woman, they would tear her apart [Bulgarian: rozcheknat - an ambiguous word possibly implying rape - M.L.]. (W, Ch, Interview 34, Garmen 2006)

M.: The people gave up their faith suffering... Massacres, blood. People actually took refuge in a church believing they'd be safe in a holy place. But they were slaughtered...

M.L.: Which church was that?

M.: The one in Batak, the Batak church. There is a poem about one Bachko Kiro who realized the situation was hopeless, first he killed his child, then his wife, and finally he killed himself. There are bloody traces on the walls which are still visible. They were all slaughtered like chickens.

M.L.: Who slaughtered them? Turks?

M.: Turks. (W, Ch, Interview 33, Garmen 2006)

According to the narrative of the old Christian women, a Batak-style massacre could have taken place anywhere; as the Turks "were sharpening their knives", there was no way of knowing where the knives would be put to use. According to my respondents, various locations were considered before the assailants finally settled on Batak. At the same time, my respondents directed their fear of a possible repeat on the Pomaks. Structurally, the narrative is reminiscent of the painting.

As Ulf Brunnbauer writes (borrowing Pierre Nora's fashionable concept of "sites of memory" or lieux de mémoire): "sites of memory operate at different levels: not only talk do they about the history of a country, but they also give local communities a chance to weave their own histories into national history, combining the 'small', local history with the 'grand' history of the nation" (Brunnbauer 2007, p. 90-91, translated from Bulgarian).

At the same time it should be pointed out that the perpetrators of the Batak massacre were predominantly Bulgarian-speaking Muslims living in the villages around Batak. In this respect Brunnbauer is correct in identifying this fact as a particularly sensitive problem in historical texts, which was consequently blanketed in silence ${ }^{198}$; serious historiography published under the Communist regime in

198 This fact is not mentioned in the information in the Batak Museum (Brunnbauer 2007, p. 95). A. Vezenkov attributes this silence the fact that "unlike before the end of the 19th century, when it 
Bulgaria actually argued that the Pomaks fought for liberation hand-in-hand with the Bulgarians (cf. Brunnbauer 2007, p. 95). 20th-century publications about the Batak massacre typically made no mention of the fact that the Pomaks came from the neighbouring villages. Instead, they identify the perpetrators as "Turks" or "fanatical Muslims” more generally (Vezenkov 2007, p. 113). Around Batak itself, the Pomaks are blamed for the massacre, whereas the general Bulgarian perception is that the massacre had been committed by Turks ${ }^{199}$ (Troeva 2007, p. 127).

Importantly, although my respondents talked about "Turks", they discussed the massacre in Batak in the context of their relations with the Pomaks, identifying it as the source their fears. This reflects a fluid transition from a fear of the Turks to a fear of the Pomaks.

According to Evgenia Troeva, Bulgarian-speaking Muslims living in the Batak area interpret the Batak massacre as an act of revenge for the forced Christianization campaign of 1912 (sic!), whereas those in the region of Ardinsko deny their involvement (Troeva 2007, p. 126-127). Many years earlier, in 1876, Muslims from Peshtera interpreted the massacre as an act of retaliation for a macabre Christian atrocity who roasted Turkish babies on spits ${ }^{200}$ (Robert J. More 1877, cited in: Troeva 2007, p. 126).

The Pomak accounts collected by Christo Popkonstantinov (1898) seem more plausible. Ten years after the massacre in Batak, Popkonstantinov's respondents from Konstandov, Banya (today part of Velingrad) and Dospat explained that the Pomaks were pushed to violence by fear caused by rumors that the inhabitants of Batak were planning to rise in rebellion as part of a planned war against Turkey, to be waged with the Russian and Serbian support (Popkonstantinov 1898), a development which would have caused justifiable concern in the Pomak population.

The stories of Bulgarian Christians being massacred at Turkish hands reflect and reinforce the idea of Ottoman domination among the Christian population. Another respondent, the metropolitan of Nevrokop, reported having actually seen bones with incision marks in a mass grave near Yakoruda, in a site discovered during archaeological excavations, which he believes is evidence of an atrocity committed against Christians which must have been hushed up by nefarious archaeologists in exchange for hush money:

made sense that Muslims/Pomaks should have been involved in a massacre of Bulgarians/Christians, by the 20th century [after Pomaks had been recognized as Bulgarians - M.L.] the same observation becomes a terrible paradox: Bulgarians slaughtered Bulgarians” (Vezenkov 2007, p. 112, translated from Bulgarian).

199 One of my female respondents, a retired elementary school teacher, argued that the massacre was perpetrated by Turks against a Pomak population (Interview 33, Garmen).

200 As the author explains, an investigation into the crime had been launched but failed to confirm this version of events. 
Metropolitan Natanail: I've seen this with my own eyes, when they dug up those graves. One archaeologist took the money and said there had been no violence, that those were willing converts to Islam. What does he mean by that given how there were visible incisions on bones of adults and children?! A broken bone does not look the same as an incised bone. (Interview 62, Hadzhidimovo 2009)

The bishop regards the new historiographical perspective on the motives which triggered Christian conversions to Islam as opportunistic and contrary to archaeological evidence.

The fears voiced by my elderly Christian respondents are mirrored by some of the Bulgarian speaking Muslims from Satovcha, who harbour similar fears about the Christian neighbours. They tell similar stories of massacres inflicted by Christians on their ancestors. It would seem that the relations of reciprocity have their macabre counterpart in the institutions of revenge and violence, and the past can be reinterpreted in many different ways.

The Muslimstories of martyrdom as narrated to meinSatovchainvariably identified Bulgarians as perpetrators, either indirectly (as agents and supporters of forced assimilation of Bulgarian-speaking Muslims), or as actal murderers participating in a massacre. According to my respondents, such a massacre took place in 1912 in the Western Rhodopes, supposedly organised by the local Bulgarians to exterminate the local Muslim elites prior to a campaign of forced Christianisation in the same year:

M.L.: Did the Muslims join the April uprising?

Woman A.: At that time, what we call a bashŭbuzuk [Turkish: başıbuzuk- M.L.] had arrived. One way or the other, they came for... here in ... they came for those who belonged to the Muslim elites...

M.L.: What does it mean, bashŭbuzuk?

A.: An autonomous army, okay?

Man H.: I can’t explain that...

A.: There were Muslims in it who were richer, smarter, more active. They took them all, our local Bulgarians did. They said they were taking them to a meeting. They went to that meeting and they were trussed up with ropes. There is a hill opposite called Bojnov Rid, that's where they slaughtered all of them. Fifty people standing in a row, all slaughtered.

Man H.: That was in 1912. It's true.

A.: My grandfather got slaughtered there. It was an evil thing that happened.

H.: Seventy people trussed up and slaughtered here over a ditch! 
A.: Right here, on that little hill, my grandfather and his brothers!

M.L.: Are they buried?

A.: No burials. They got thrown into a ditch!

H.: Yes, they're in some hole. All of them in some hole.

A.: It was the local Bulgarians who did that, our people!

M.L.: Meaning, the local inhabitants?

A.: The locals. Grandfather was slaughtered by our neighbours!

M.L.: In 1912?

H.: In the 12th year. (Muslims, Interview 29, 2005)

My respondents revisited this topic several times and were visibly emotional, expressing sympathy ${ }^{201}$ for the victims:

Man H: Do you believe that the skies opened? [The respondent is quoting his conversation with another man - M.L.] - I do. - Did you see it? - I did. - Interesting, because they all prayed, those were hodzhas, people who knew the Qur'an, and they went there, praying. They were told there would be a meeting, a talk at the culture center. They were all gathered in one building.

M.L.: How many were slaughtered?

H.: Seventy people, seventy... The smart ones, the open-minded ones...

Woman A.: The more prominent ones, who knew..., because there was talk for them. You know, a talk, rech; it's vajdis in Turkish ${ }^{202}$ ?

H.: A lecture given before an audience.

A.: [The respondent speaks very indistinctly] and they slaughtered them there.

M.L.: But they said that it would be a talk?

H.: Yes.

A.: In the evening they took them to the culture center for a talk.

201 As K. Kaniowska notes, this is a distinguishing quality of post-memory which it characterizes as "a narrative about a narrative, as emotional (if not more) as the original one" (Kaniowska 2004, p. 21, translated from Polish).

202 Perhaps the respondent means "news” (in Turkish the word havadis means 'news'). 
H.: Like it was going to be a meeting.

M.L.: Meaning, they did that in the culture center?

A.: They told them to come. They got them all into one building. (Muslims, Interview 29, 2005)

One characteristic of postmemory narratives is the tendency to sacralize and exalt "unexperienced traumatic past” (Kaniowska 2004, p. 21, translated from Polish), a sentiment which is palpable in the following comment:

Man H.: At night it got terribly bright. That's why they say the skies opened ... I believe it because I've asked the Christians [if that was true]. I thought, maybe our Muslims are embellishing things a bit. Because my grandfather and my grandmother remembered. They told me about.

M.L.: What do you call this event around here?

H.: The slaughter. I don't know, the slaughter.

Woman A.: The slaughter of 1912.

H.: In 1912. I don’t know why they slaughtered them.

A.: I don’t know why. Our grandmother said...

H.: I ask Christians, elderly people..., and he told me, he said it quite clearly. (Muslims, Interview 29, 2005)

It is impossible to say whether or not the massacre in Satovcha is an actual historical event $^{203}$. On the one hand, the event is located in a not too distant past, and relates to the life of the grandparents of my respondents, on the other hand that is not enough evidence to treat those accounts as factual. I have consulted Bulgarian scholars working on the Ottoman period but they were unable to resolve the historicity of the events of $1912^{204}$. But perhaps the factual truth of those narratives is not what matters. Ethnographers are more interested in the symbolic power and impact of such narratives, seen through the lens of social constructs and collective images rather than as historical facts. Accordingly, it makes sense to pose the question, what is the meaning behind the structure of those narratives and the analogies between the

203 According to Rosner, every account can be put into question and none enjoys absolute credibility (Rosner, cited in: Kaniowska 2004, p. 25).

204 Some historical sources provide evidence of massacres of Muslims being perpetrated in Bulgaria in 1913, lending credibility to the accounts shared by my respondents. H.T. Norris quotes a confidential letter to C. M. Warling, chargé d'affaires in Constantinople dated 17th of July 1914 from the British Consulate General in Thessaloniki reporting that "at the beginning of the Balkan War against Turkey many massacres of Moslems were carried out by Bulgars in various parts” (Norris 2006, p. xi). 
two religious groups, with the changing roles of perpetrator and victim. In view of the above, such narratives can be categorized as memorata ${ }^{205}$ (Tokarska-Bakir 2008, p. 121).

According to the Muslim accounts, the Christians gathered their victims (numbering fifty or seventy, depending on the version) into one place under the pretext of a meeting, then chained them on a hill (Bulgarian: navŭrzani na edin sindzhir, tam na edin bair) and slaughtered them. Aksime said that her grandfather and grand uncle were murdered on that occasion.

According to the narrative, the skies opened during this atrocity which scared the perpetrators who failed to finish off one of the victims, who only got killed the following day. The component elements of this narrative can also be found in Bulgarian folklore, such as the song Gora i tri sindzhira robi (The Forest and the Three Ropes of Slaves). In the song, a shepherd asks the Forest why it's all withered when it was green just the day before. The Forest explains that the cause of the withering is its compassion for rope-bound slaves who had been driven through it:

The first row, oh shepherd

Was all young girls.

When girls cry

The forest bends the treetops ...

The second rope, oh shepherd,

Was all young women.

When women cry,

The forest loses its leaves.

The women cry and wail,

“Oh God, dear God!

Our little babes

205 J. Tokarska-Bakir defines a memorate as "testimony of individual experience shaped by the grammar of collective imagination" (świadectwo indywidualnych przeżyć, uformowanych wedtug gramatyki wyobrażeń zbiorowych) (Tokarska-Bakir 2008, p. 121). In this case, the memorate bear no relationship to religion (in Propp's typology, the memorate is “a story with religious content” (Propp 2012, p. 26), but Tokarska-Bakir treats them as tales of collective historical trauma experienced by a religious group. 
Left motherless in the morning,

Crying for their mothers, asking

If their mother is milking the cows?

The third row, oh shepherd,

Is all young lads,

When lads cry,

The branches in the forest wither" (Gora... 1965, p. 214)

Although the song talks about Christian slaves in Ottoman times, Muslims create analogous narratives of martyrology. Cohabitation in a geographical area not only promotes good relations between neighbours but also gives rise to monuments of martyrology for each religious group. In the case of Christians, this has become sublimated into an official site of national memory, in this case the museum in Batak. In the case of the Muslims, the site of memory is located on a hill in the outskirts and is not physically commemorated. Muslims, my respondents went on to explain, are a majority in the local government, but they are unwilling to erect a memorial to commemorate the atrocity for fear of antagonizing the Bulgarians. The postmemory of the event is passed on in oral form by the older respondents:

M.L.: Where exactly is the site of the slaughter?

Woman A.: At the end of the village, on the hill.

M.L.: Is this place somehow marked now?

Man H.: No, there is nothing. It's forgotten.

M.L.: Don't you want to put up a memorial of some kind?

A.: We don't.

H.: We all keep silent, nobody wants to do anything.

A.: We are afraid, what can we do?! They will come again.

H.: Nobody will care.

A.: We live together, we celebrate together, we drink together but we are afraid! This feels like living under a yoke. My grandfather was stabbed with a knife eighteen times. (Muslims, Interview 29, 2005) 
Significantly, the narratives are almost identical in terms of structure and content but they differ greatly in terms of impact. The Muslim narrative remains marginal, relative to the Christian narrative. With no historical accounts or outward forms of commemoration it becomes relegated to the level of legend. The Christian narrative of the massacre in Batak becomes one of the variants of the official narrative of national martyrology. Despite the efforts of many modern historians who have attempted to rethink this element of Bulgarian consciousness as a myth rather than a historical account, the symbol remains deeply rooted in Bulgarian collective memory, and stubbornly resisting any debunking efforts.

The narratives express the latent fears which both group harbors for noncoreligionist neighbours officially treated as "brothers" and "people like us" in the komshuluk narrative because the neighbours could betray the ideals of good relations between neighbours if the political situation became volatile. Both groups expressed their fears in a very graphic way: the eighteen stab wounds mentioned by the Muslim woman, the slitting of throats in the narrative of the old Christian women. The Muslims continue to fear new assimilation efforts from the Bulgarians. One Muslim respondent said that they could no more become Bulgarians than an animal could become a member of a different species:

M.L.: So, your life with the neighbours, is it good?

Woman A.: It's a life...

M.L.: Are you afraid, all the same?

A.: We are afraid.

Man H.: We have a good life together, but, like she said, everybody was in favor of us becoming Christians.

A.: [So that we become - M.L.] one thing. But we resist that. Can you turn as sheep into a goat, or a cow into an ox?!

H.: The locals, all of the locals.

A.: You can't turn a cow into an ox, and we will never be Bulgarians. We've changed our faith.

H.: So now, when we sit together, we get no support from them, on the contrary.

A.: None.

H.: On the contrary.

A.: We sit on a bench, we start talking.... They are ready to trample us underfoot. 
H.: They have a bad attitude. And they have this idea... I'm not sure if they can understand it... [The respondent shares his doubt with the women whether myself and my companions can understand the topics] from communist times.

A.: Not just communist times, they changed them [the names] already during fascist times.

H.: He said it. Leave us alone!

A.: We are being persecuted on a regular basis, Muslims in Bulgaria are. Regular persecution! That's what it's like! (Muslims, Interview 29, 2005)

The subject is obviously emotionally charged. My respondents revisited it several times and expressed their emotions using the same phrases:

Woman A.: Bulgaria always persecutes Muslims. Always. They want to make a single nation out of us.

Man H.: A nation, a single state, a single nation.

A.: But we don't want them. An ox can't turn into a cow, and a cow can't turn into an ox. (Muslims, Interview 29, 2005)

In view of the frequent official attempts of the Bulgarian state to assimilate the Pomaks in the past, the respondents are concerned that the pressures might repeat themselves:

Woman A.: Some time passes..., and it starts all over again... We can't get a moment's respite.

M.L.: Why is it like that?

A.: Persecution. They want to make Bulgaria ...

Man H.: In '12 they would change their names and they'd actually baptise Muslims. It wasn't just the names, either. Now it was just the names, that was a bit more gentle [Bulgarian: posmekchavashto - M.L.]. In the past, they used to summon them to churches, baptise them. They made attempts like that in [19]30, [19]40... Loads. In [19]73 everyone was affected, it was a mass thing. (Muslims, Interview 29, 2005)

The older female Orthodox respondents were concerned that the close relations with their Muslim neighbours might fall victim to a potential situation of armed conflict:

Woman 1: Now listen, let me tell you something. We live very well together. But if anything happens, God forbid, they will slaughter us like mice.

M.L.: What is it that could happen?

Woman 1: If there is a war, we'll all get slaughtered by the Pomaks. 


\section{M.L.: Are you afraid?}

Woman 2: Of course we are. (Christians, Interview 25, 2005)

Considering the narratives of my Christian respondents, I suppose there must be a strong symbolic connection between the events of 1876 and 1912. Those events give rise to mutual mistrust and feelings of ressentiment in both groups. Each group believes the other to be capable of random acts of hostility and violence, and sees itself as a potential victim at the hands of the neighbours who can be easily manipulated by politicians. The question arises, where does the ressentiment originate?

It would seem that in both cases there is sent on stems from humiliation and grudges harboured for the other group on account of its violent past. For the Orthodox Christians, this probably stems from the "slavery complex" of the 500 years Bulgaria spent under Turkish yoke, a period believed to be the cause of Bulgaria's underdevelopment and the historical rupture separating the country from its Byzantine/Thracian/proto-Bulgarian roots (depending on a particular narrative). In this sense, the Pomaks are seen as an embarrassment: victims of Ottoman oppression who have "turned Turk". They are pitied for their victim status, but at the same time they are regarded as traitors who cling to the "faith of slaves". Perhaps this is why my respondents talking about the massacre in Batak cited many examples of the humiliations suffered by Bulgarians had Turkish hands and leading to the local population "turning Turk", which involved rapes of girls and pressing boys into janissary units. Two of my respondents cited the words of a song about forced conscription into janissary units, which they treated as a historical account:

D.: Aaah, we used to sing a song: "Mother, there are janissaries going from village to village, snatching male children and turning them into janissaries" [the respondent can't remember the exact words and paraphrases them - M.L.]. Generally, there are those accounts of children playing outside who were snatched by Turks and taken into Turkey. They were taught Turkish and pressed into service as janissaries, evil men. The boy came here to see his mother. He didn’t recognize her and he wanted to... But he had some kind of birthmark, and the mother recognized her child. She said to him: "Don't kill your own mother! Your mother gave birth to you, and the Turks kidnapped you turned you into a janissary." And some things came back to him, the places where he used to play, and he saw that it was his own mother. They embraced and kissed. Then the Turks took him away, they took him into Turkey and killed him there. (W, Ch, Interview 41, Garmen 2006)

Woman 1: You know what, in the past they used to go around the area and snatch up boys: "The janissaries are coming, taking our sons away" [a snatch from a song - M.L.]. They would take boys and turn them into janissaries. They took a small Bulgarian boy in these parts, and when they showed up here [years later] he wanted to butcher his own father. He'd turned into a beast! He wanted to butcher him. It's in one of those songs...

Woman 2: He did kill him!

Woman 1: He killed his own father! 
M.L.: Did he realize it was his own father?

Woman 2: He knew he was his dad, but he was a janissary now. Doing as they said... He was a monster.

Woman 1: A monster.

Woman 2: Completely callous. (Christians, Interview 25, 2005)

According to my respondents, Bulgarian girls would be kidnapped and raped, which meant they would "turn Turk":

Woman 1: We used to have this water well in the market square, the water used to come out of two pipes.

Woman 2: A spring.

Woman 1: A spring. And when a young girl came to fetch some water, the Turks would catch her and turn her Turk.

M.L.: Does that mean they would somehow convert to Islam?

All: Yes.

Woman 3: That was during the Turkish rule.

M.L.: So, how exactly did they turn the girls Turk?

Woman 1: Well, they turned them Turk, to make sure they'd be Turks. (Christians, Interview 25, 2005)

The respondents apparently treated rape and conversion to Islam as synonymous, as suggested by the phrase "the Turks would catch her and turn her Turk". They were reluctant to use the word "rape" because of its shameful connotations, and substituted the phrase "to turn Turk" as a synonym: "Well, they turned them Turk, to make sure they'd be Turks". When pressed for answers, they would add that "turning Turk" also involved wearing traditional Turkish clothes such as shalvari or feredzhe. The respondents several times emphasized that Bulgarians yali sa mnogo mŭka (suffered greatly at Turkish hands):

Woman 1: The Bulgarians suffered so much! So much! They would pick and choose the girls...

Woman 2: The prettiest ones. There was this movie where they locked them in some kind of cart, young girls, very young, and they "turned them Turk". Those were very evil times!

M.L.: So, what did they do exactly? 
Woman 2: Well, later they dress them in Turkish clothes, shalvari trousers and cloaks. (Christians, Interview 25, 2005)

The respondents repeatedly referred to literary sources, films and works of art which had shaped their postmemory.

Coming back to the subject of rape, they decided to add more details and explained that the women would be raped from behind, the most humiliating position for the woman. This way, the Turks are made to look like primitives, a constant threat to Bulgarian girls:

Woman 1: If you'll excuse me saying that, they caught some women here. A woman told the story. And the Bobovlaiko would choose those best dressed ones, and told them to collect ears of wheat. Told them to collect the wheat naked, and they would be free to do their business from behind as they pleased. (Ch, Interview 25, 2005)

This reference to rapes committed by Turks on Bulgarian women should also be taken in the metaphorical sense as an expression of the humiliation experienced by Bulgarians under Turkish occupation, seen as a "contamination"of Bulgarian culture, bodies and souls by Turkish influence. Topics such as killings, rapes and kidnappings of Bulgarian women at the hands of Turks were obviously a popular subject in Bulgarian folk songs and national literature, were Turks tend to be portrayed as cruel and primitive barbarians:

"The Turks enslaved to this land

They loved the young

They enslaved the old

They butchered the little children” (Turtsi... 1963, p. 218)

Such motifs were present in school knowledge and were previously available in the history and literature textbooks which shaped the Bulgarian national martyrology. Such images reinforce in the Orthodox Christian population theidea that the ethnonym Pomaks referred to Bulgarian people "martyred" and "tortured" by the Turks who chose to save themselves by converting to Islam and "losing" their Bulgarianness:

M.L.: Okay, but aren’t the local Muslims Bulgarians?

Woman 1: They are not Bulgarians. They are, just look here, sine ${ }^{206}$. We say that they have turned Turk. We have villages here such as Valkosel and others, Slashten. Another village, Fargovo,

206 Literally, "son", a customary form of addressing younger people by their elders in the Rhodopes irrespective of gender, a symptom of the patriarchal nature of the local culture. 
all of those people are Pomaks now. They've turned Turk, that's what we say. They all used the Bulgarian, now they've all turned Turk.

Woman 2: They call them “Muslim Bulgarians”. (Christians, Interview 25, 2005)

On the Pomak side, the hidden ressentiment comes from the way Bulgarians tend to regard their faith as an act of "turning Turk" and generally the "revival process" itself. Paradoxically, both ressentiment narratives are narratives of colonized populations: each group constructs them around its own "wounded identity": in the case of the Christians, the humiliation comes from the experience of Turkish occupation, in the case of the Muslims it stems from the experience of repression during the process of revival. Latent mutual fears are suppressed to protect the positive relationship. Whereas the good-neighbourly narrative presents Muslims and Christians as brothers, the ressentiment narratives presents them as monsters.

This seems to echo Max Scheler's observation that "It goes without saying that genuine moral value judgments are never based on ressentiment. This criticism only applies to false judgments founded on value delusions and the corresponding ways of living and acting” (Scheler 1998 [2010], p. 23).

\section{5 "The Politicians are to Blame for All of This"}

Although the narratives of both religious groups reveal mutual fears and feelings of ressentiment, they do not see this as an imminent threat to Good relations between neighbours, which are seen by both groups as a value in itself. Should a potential threat to peaceful relations arise, the respondents tend to hold politicians responsible:

M.: We live well together, in human terms. There are no problems. The problems are caused by politics, by the government. (W, Ch, Interview 33, Garmen 2006)

Mufti: Wherever there are Muslims, people live together... It doesn't matter if there are other religious communities living in their midst. They say, unless the politicians stoke up some conflicts, there will be no confrontation between us. All the wars, all those things are the work of politicians... (Interview 18, Ribnovo 2005)

This sentiment mirrors similar comments collected by Peter Maass from his respondents in Bosnia: "We are lived in Vishegrad like a big family, the Muslims and Serbs ... Everyone had mixed marriages. We never tried to find out who was a Serb or Muslim. We didn't look for differences. You know, it wasn't the people who wanted to fight. It was the politicians who prepared this stew, and now we can never go back" (Maass 1996, p. 11).

Some of my respondents did not doubt that politicians were capable of turning Bulgaria into "a second Bosnia" while others felt this was completely out of the question. 
In general, the respondents realized that the historically changing relationships of power were capable of stabilising or unsettling the symmetry of mutual relations. In the Ottoman Empire, Muslims were in a privileged position compared to Orthodox Christians, a situation that became reversed in Bulgaria. Muslims still dominate in most local councils in the Western Rhodopes. This causes concerns among the Christians, a fact that Muslims realise ${ }^{207}$ :

A.: Now the Bulgarians are upset because our Muslims are in the majority: the mayor, the forester, Ayshe [the school principal - M.L.] are all Muslims. So now the Bulgarians are jealous. They are in power in Bulgaria now, so you get this kind of political jostling. (W, M, Interview 29, 2005)

Christians in the area tend to feel dominated by the Muslims (not only Pomaks but also Roma people, both in Garmen and Satovcha). They complain about their inability to get a Christian mayor elected:

I.: When we follow the politics with [Ahmed - M.L.] Dogan ${ }^{208}$, with this one and that. We see that they stick together.

M.L.: Meaning, you vote for different people?

I.: Our numbers are shrinking, theirs are not. That's why I said yesterday that we can't get our mayor elected, we Bulgarians. The numbers are not big enough. And it's going to be worse a few years down the line, when the Roma are in power. The Pomaks, they speak good Bulgarian and we can understand each other, but you can't understand a Roma. (M, Ch, Interview 43, Garmen 2006)

Woman Y.: They enjoy all kinds of privileges but we don’t, it’s like we don’t even have them...

Man 3: Meaning, the Roma and the Muslims are supported by all kinds of foundations, and they get money from them. But we, we sometimes have to scramble just to put soup on the table or to buy bread... (Christians, Interview 53, 2005)

Politicians often exploit such fears in political campaigns. The emergence of ATAKA ("Attack"), a Bulgarian nationalist party which won parliamentary seats in the 2005 election, provoked fears among Muslims concerned about the rise of nationalist sentiment in the country.

I could witness this kind of political rhetoric in the spring of 2009 when a Bulgarian MP, Yane Yanev, representing the conservative party Order, Law and Justice (Red, zakonnost i spravedlivost, RZS) and Dimitar Abadjiev (independent) appeared on

207 In Satovcha the Muslims refused to rename a street named after a local Communist, a partisan named Shopov, for fear of antagonizing the Christians.

208 Founder and former chairman of the Movement for Rights and Freedoms (DPS. Dvizhenie $z a$ prava i svobodi), a centrist party in Bulgaria. 
Bulgarian television to sound alarm about a process of Islamisation allegedly taking place in the Western Rhodopes ("Sutrin", 17 March 2009). The title of the program was, Does Islam rule in the Rhodopes? The politicians and the journalists repeatedly used the term "radical Islam" but were content to leave it vague and undefined. The politicians behind the furore showed no evidence in support of their alarmism even though they actually named some individuals they felt were responsible for the reIslamization of the region, namely Ahmed Bashev (mayor of Garmen) and hodzha Murat Boshnak ${ }^{209}$.

The furore was triggered by a ceremony celebrating the opening of a new sanitation system in Ribnovo, which involved a prayer in Arabic led by hodzha Murat, the teacher of religion in the local school. Media reports claimed that the hodzha demands to be addressed as Aga ${ }^{210}$ (Turkish, "Lord") by his pupils, an allegation the hodzha dismissed. Importantly, the word aga has negative connotations in Bulgarian society, evoking the times of Ottoman rule, when the word was used to address highranking Turkish officials ${ }^{211}$.

Yane Yanev and Ahmed Bashev later met with hodzha Murat in "Seysmograf", a TV programme (7 March 2009). The program escalated to a sharp exchange of views between the politicians. Apparently, Yanev notified Bulgaria's State Agency for National Security (DANS) that he received a death threat from Bashev, which led to Bashev and hodzha Murat's arrest; the men were released after six hours of interrogation.

The media broadcast the euphoric welcome given to Bashev in the market square of Ribnovo, where he was carried by the local inhabitants chanting his name. The mayor addressed the crowd from the pulpit, calling for calm and tolerance. Wrapped in a Bulgarian flag and holding an EU flag in his hand, Bashev was trying to create a media image of the Pomaks as loyal Bulgarian citizens with pro-European attitudes ${ }^{212}$.

209 Because the story was aired in nationwide media I take no steps to conceal his identity, especially as my book shows the respondent in a much more favourable light than the sensationalist media reports.

210 "A military honorific applied to officers of various ranks including the highest status officers from the janissary corps" (Todorova 2004, p. 469), the title later became applied to men of authority (Norris 1993, p. xiv).

211 On a family trip to Macedonia I heard a relative say that a Macedonian passing a Turk in the street would have to bow down and greet him with the words, “100 godini aga!” (,May you live to be one hundred, Aga”).

212 Ribnovo and Garmen began to attract media attention: television reports showed girls from Ribnovo wearing traditional clothes. Interviewers asked the girls whether they were forced to wear the traditional costume or take religious education in the school. Questions were raised whether headscarves were constitutional in Bulgaria. The head of the village explained that the clothes were "a matter of tradition in Ribnov, it had nothing to do with religious garb and wearing it is nothing wrong” (BTV Novini, 17 March 2009). A reporter, A. Chekimian, pointed out that other kinds of clothes were also warn in Ribnovo. The village head explained that the other type of clothes came from Arabia 
I spent many hours taking to the mayor and watching him interact with family members and other people including non-Muslims, and I can emphatically deny that he is promoting radical Islam.

This short summary of the events in Ribnovo illustrate not only the impact of politics on the life of the community, but also the ways in which the media may shape community life. Ultimately, social sentiment seems to be guided by television anchors and reporters, and not by the invited guests such as sociologists, religious scholars or other experts. The opinions of the media personality Slavi ${ }^{213}$ seem to be immensely influential - the opinions of social scientists, not so much.

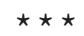

My field research in the region of Gotse Delchev in the Western Rhodopes suggests that the strategy of peaceful coexistence developed by the two religious groups is a bottom-up cultural strategy which offers an antidote to the historical ressentiment harboured by both groups and prevents future bloodshed. Fulfilling one's obligations towards non-coreligionist neighbours quells mutual fears and proves the value of peaceful coexistence based on do ut des arrangements. Fears and concerns make the local community highly sensitive to (global, top-down) political change as a harbinger of ressentiment boiling over into hostilities. Whereas one code is predicated on the principle of symmetry (as expressed in the rule of do ut des) to guarantee peace, the other brings the threat of possible retribution for past bloodshed. Unless the situation becomes destabilized by political goading and general political deterioration, the arrangement seems stable.

in 1989 and was not related to radical Islam but rather with "the need to practice religion in the Qur'anic way” (BTV Novini, 17 March 2009). The Ministry of Education audited the schools in Ribnovo to check for irregularities. At the request of one of the inhabitants of Satovcha an education inspector named Ognian Sokolov audited the schools for irregularities in the teaching of Islam, and concluded that there was no evidence of tensions in the school where $40 \%$ of the staff were Christian and $60 \%$ were Muslim. An audit of the Ministry of Education conducted in the school in Ribnovo, focusing particularly on its teaching of Islam (BTV Novini, 18 March 2009), likewise confirmed that the school's teacher of religion, Murat Boshnak, held the necessary credentials from the Higher Islamic Institute in Sofia.

213 Shouto na Slavi, a popular talk show on Bulgarian state television hosted by Slavi Trifonov featuring interviews with celebrities and politicians. The programme's website contains a claim that Slavi Trifonov has been polled to be one of Bulgaria's top five most-trusted people: http://www. slavishow.com/index.php?cat=1\&mid=100\&id=5987 (19.01.2012). 